\title{
PELATIHAN PAKEM MATEMATIKA SD DENGAN MENGGUNAKAN KOTAK KPK DAN FPB BAGI GURU SD DI KECAMATAN PONDOK KELAPA
}

\section{TRAINING OF MATHEMATIC PAKEM BY USING KPK AND FPB BOX FOR TEACHER OF ELEMENTARY SCHOOL IN DISTRICT OF PONDOK KELAPA}

\author{
Oleh: \\ Nurul Astuty Yensy ${ }^{1)}$ \\ 1) Program Studi Pendidikan Matematika JPMIPA FKIP Universitas Bengkulu \\ nurulastutyyensy@yahoo.com
}

\begin{abstract}
This activity aims to provide knowledge to teacher of elementary school about learning of mathematic PAKEM by using tool kit of KPK and FPB box in district of Pondok Kelapa and the manufacture technique, to motivate the teacher in order to create an innovative and creative mathematic learning media for the students. The training used the various methods such as workshop, demonstration, question and answer, discussion, guiding duties, monitoring and evaluation. The audiences in this activity were the teachers of SD N 10 Pondok Kelapa and SD N 2 Pondok Kelapa Central Bengkulu. Before the activity, the teacher knowledge about mathematic PAKEM was relatively less that only 9,1\% know it, After the activity the ability and skill of the teacher in making the teaching toolbox of KPK and FPB is good (83\%), They produced this props with good results and can be applied to mathematic subject. The teacher's motivation to participate in this training is good (positive responses of participants in questionnaire by 95\%).
\end{abstract}

Keywords: learning of mathematic PAKEM, KPK and FPB box, elementary school.

\section{PENDAHULUAN}

Di tingkat Sekolah Dasar, keberhasilan belajar siswa hampir seluruhnya terletak pada usaha guru untuk memahami proses belajar siswa. Bila guru melaksanakan kegiatan belajar mengajar (KBM) diharapkan akan mengandung makna bahwa: guru tersebut mempunyai aktifitas mengatur kelas dengan sebaik-baiknya dan menciptakan kondisi yang kondusif sehingga siswa dapat belajar dengan baik. Belajar di sini mengandung arti bahwa siswa aktif melakukan kegiatan yang bertujuan.

Guru dalam merencanakan suatu proses pembelajaran, sekurang-kurangnya faktor yang umumnya harus dipikirkan secara simultan oleh guru antara lain adalah: tujuan yang akan dicapai, materi pembelajaran, siswa, media pengajaran, metode pembelajaran dan waktu belajar (Suparman, 1997). Tanpa mengabaikan faktor yang lain, faktor-faktor tersebut secara bersama-sama menentukan hasil dari proses pembelajaran yang terjadi. Kualitas dan produktivitas pembelajaran ini akan tampak pada seberapa jauh siswa mencapai tujuan pembelajaran yang telah ditetapkan. Sementara itu, untuk membuat siswa 
mencapai tujuan pembelajaran yang telah ditetapkan tersebut terkait erat dengan efektivitas strategi pembelajaran yang disusun oleh guru. Untuk itu, salah satu tugas guru adalah bagaimana menyelenggarakan pembelajaran efektif sehingga lebih bervariasi, menarik dan menyenangkan.

Namun demikian, kenyataan di lapangan (Depdiknas, 2005) menunjukkan sebagian besar guru masih mengalami kesulitan bagaimana menyelenggarakan pembelajaran yang efektif, khususnya pembelajaran matematika di SD. Pembelajaran yang dilakukan masih berpusat pada guru, serta pendekatan abstrak dengan metode ceramah dan pemberian tugas sangatlah dominan dari setiap kegiatan pembelajaran. Sangat jarang dijumpai guru merencanakan pembelajaran matematika dengan pendekatan nyata yang mengaktifkan siswa, karena mereka menganggap bahwa pembelajaran yang demikian tidak bermanfaat, membingungkan dan menyita banyak waktu. Disamping itu, kenyataan menunjukkan bahwa bekal kemampuan materi matematika dari guru SD masih kurang memadai.

Kesulitan dalam menyelenggarakan pembelajaran matematika SD tersebut di atas, juga dialami oleh guru-guru SD di Kabupaten Bengkulu Tengah (Benteng), khususnya di Kecamatan Pondok Kelapa. Kecamatan ini merupakan salah satu diantara 10 kecamatan yang ada di Bengkulu Tengah, dengan jumlah desa dominan lebih banyak (20 desa). Diantara desa tersebut adalah Desa Harapan dan Desa Pondok Kelapa. Berdasarkan survei awal ditemukan bahwa di SD Negeri 10 Pondok Kelapa (Desa Harapan) dan SD Negeri 2 Pondok Kelapa (Desa Pondok Kelapa), pembelajaran matematika yang diselenggarakan oleh guru kelas masih bersifat konvensional yaitu metode ceramah. Guru masih mengalami kesulitan dalam mentransfer konsep matematika yang bersifat abstrak kepada siswa khususnya materi Kelipatan Persekutuan Terkecil (KPK) dan Faktor Persekutuan Terbesar (FPB), padahal materi ini adalah salah satu materi dasar yang diberikan di kelas IV SD, sehingga di kelas tingkat lanjut (kelas $\mathrm{V}, \mathrm{VI}$, dst) siswa diharapkan telah menguasai konsep KPK dan FPB, sedangkan kenyataannya $>50 \%$ siswa kelas V maupun kelas VI yang masih salah dalam memahami konsep KPK dan FPB ini. Selain itu, media pembelajaran seperti alat peraga matematika relatif masih kurang memadai, apalagi alat peraga untuk menanamkan konsep KPK dan FPB sama sekali belum ada. Hal ini berdampak juga pada motivasi belajar siswa yang rendah, tidak aktif dan tidak kreatif sehingga secara tidak langsung menunjukkan pembelajaran yang terjadi tidak efektif dan kurang menyenangkan.

Selanjutnya, jumlah guru di SD Negeri 10 Pondok Kelapa dan SD Negeri 2 Pondok Kelapa relatif cukup banyak yaitu masing masing 14 orang dan 17 orang, ditambah 3 guru honorer di SD Negeri 2 Pondok Kelapa. Berdasarkan wawancara dengan salah seorang guru kelas IV SD Negeri 10 Pondok Kelapa yang mengajarkan matematika materi KPK dan FPB mengatakan bahwa mayoritas guru kelas mengalami kesulitan dalam mengajarkan matematika kepada siswa. Hal ini karena mereka kurang menguasai bagaimana mengajarkan konsep matematika agar terlihat lebih konkret. Biasanya mereka lebih banyak memberikan rumus-rumus matematika, contoh soal dan latihan kepada siswa. 
Khusus materi KPK dan FPB, mereka sama sekali belum berpengalaman menggunakan media pembelajaran atau alat peraga sebagai alat bantu pembelajaran.

Arikunto dalam Herlina (2005) mengemukakan bahwa alat peraga sebenarnya harus diusahakan adanya di sekolah agar materi yang diberikan kepada murid dapat lebih mudah ditangkap. Alat peraga dapat menyajikan hal-hal yang abstrak dalam bentuk benda-benda atau fenomena-fenomena konkret yang dapat dilihat, dipegang, diubah-ubah sehingga halhal yang abstrak lebih mudah dipahami. Alat peraga merupakan salah satu dari media pendidikan yakni alat untuk membantu proses belajar mengajar agar proses komunikasi dapat berhasil dengan baik dan efektif.

Permasalahan selanjutnya adalah tidak semua guru di sekolah terutama guru di tingkat Sekolah Dasar mampu membuat atau merancang alat peraga pembelajaran sebagai alat bantu di sekolah sehingga pembelajaran lebih efektif dan menyenangkan serta siswa lebih aktif, karena memang dalam pelaksanaannya tidak mudah, dan membutuhkan pemikiran inovatif dan kreatif serta waktu yang cukup lama, sehingga dalam kegiatan ini dilakukan sosialisasi dan pelatihan PAKEM (Pembelajaran Aktif, Kreatif, Efisien dan Menyenangkan) matematika SD dengan Menggunakan kotak KPK dan FPB bagi Guru Sekolah Dasar di Kecamatan Pondok Kelapa Kabupaten Benteng.

Pembelajaran Aktif dimaksudkan bahwa dalam proses pembelajaran, guru harus menciptakan suasana sedemikian rupa sehingga siswa aktif bertanya, mempertanyakan, dan mengemukakan gagasan. Kreatif dimaksudkan adalah siswa mampu menghasilkan sesuatu untuk kepentingan dirinya dan orang lain. Efektif artinya menghasilkan apa yang harus dikuasai siswa setelah proses pembelajaran berlangsung atau tercapainya tujuan pembelajaran. Menyenangkan adalah suasana belajar mengajar yang menyenangkan sehingga siswa memusatkan perhatiannya penuh pada pembelajaran (Depdiknas, 2005).

Kotak KPK dan FPB merupakan alat peraga yang dibuat sendiri untuk menanamkan konsep tentang KPK (Kelipatan Persekutuan Terkecil) dan FPB (Faktor Persekutuan Terbesar) yaitu salah satu materi matematika yang mulai dipelajari di kelas IV SD. Kotak yang dimaksud adalah seperti pada gambar 1 berikut:

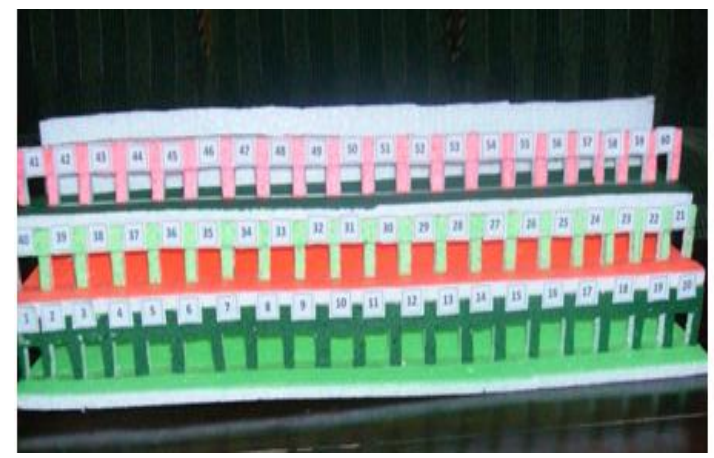

Gambar 1. Alat Peraga matematika (Kotak KPK dan FPB) 
Cara pembuatan kotak KPK dan FPB tersebut adalah sebagai berikut:

1. Siapkan alat-alat (gergaji gabus, gunting, silet, mistar, pensil, lem dan solatif) serta bahan-bahan (spon warna dan kertas warna)

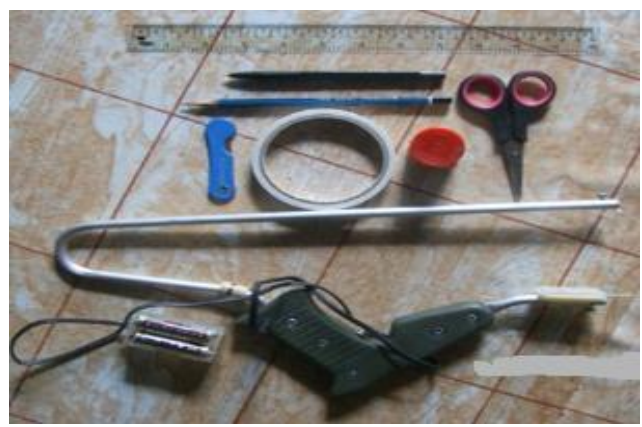

Gambar 2. Alat-alat

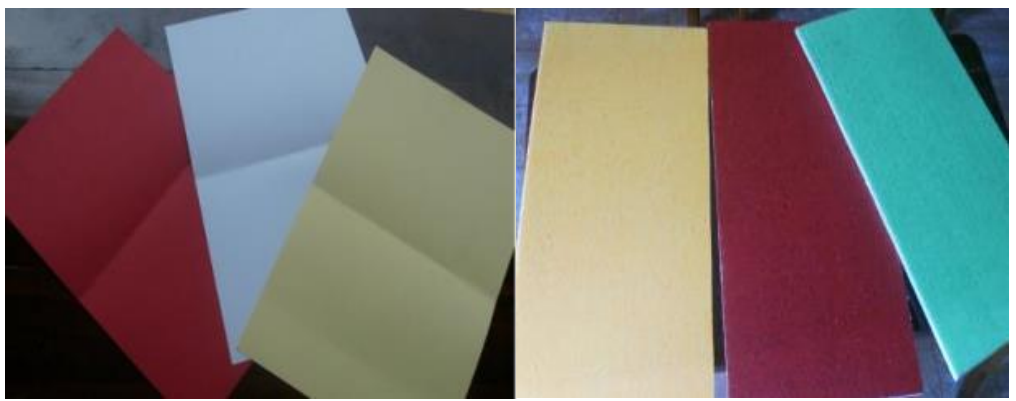

Gambar 3. Bahan-bahan (kiri: kertas warna; kanan: spon warna)

2. Potong gabus (spon warna) dengan ukuran 4 x $98 \mathrm{~cm}$, lalu bentuk masing-masing gabus seperti gigi gergaji dengan lobang 20, dan rangkai gabus yang telah dipotong dengan menggunakan solatif. Selanjutnya potong kertas warna dengan ukuran $0,9 \mathrm{x}$ $13 \mathrm{~cm}$, dan buat label angka $1 \mathrm{~s} / \mathrm{d} 60$ (tempel di baris pertama dari kanan ke kiri $1 \mathrm{~s} / \mathrm{d}$ 20, baris kedua dari kiri ke kanan $21 \mathrm{~s} / \mathrm{d} 40$ dan baris ketiga dari kanan ke kiri $41 \mathrm{~s} / \mathrm{d}$ 60). Secara lengkap lihat gambar berikut:

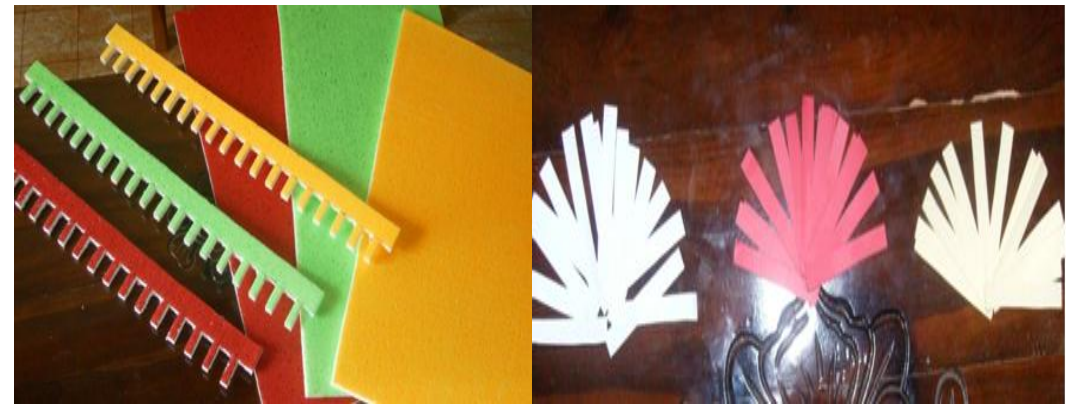




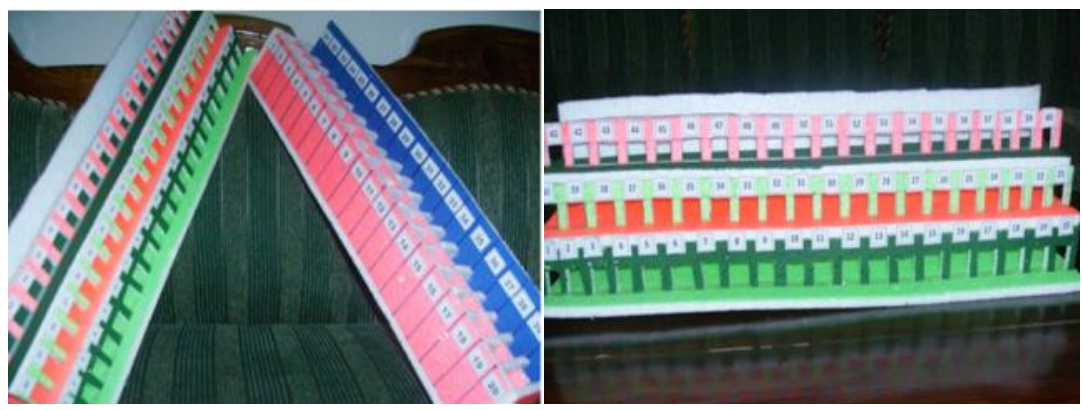

Gambar 4. Tahap pembuatan alat peraga kotak KPK dan FPB

Kegiatan ini bertujuan untuk memberikan pengetahuan kepada guru-guru SD tentang PAKEM matematika SD dengan menggunakan alat peraga yaitu kotak KPK dan FPB di Kecamatan Pondok Kelapa Kabupaten Bengkulu Tengah serta teknik pembuatannya. Selain itu juga untuk memotivasi guru-guru SD agar dapat menciptakan media pembelajaran matematika yang inovatif dan kreatif bagi siswa.

Dengan adanya kegiatan ini diharapkan guru-guru SD khususnya di Kecamatan Pondok Kelapa Kabupaten Bengkulu Tengah memiliki pengetahuan tentang PAKEM matematika SD dengan menggunakan kotak KPK dan FPB, memiliki kemampuan membuat alat peraganya, dan memiliki motivasi yang tinggi untuk membuat alat peraga matematika yang inovatif dan kreatif.

\section{METODE PENGABDIAN}

Metode pelaksanaan pengabdian yang dilakukan adalah sebagai berikut:

1. Metode ceramah/presentasi/seminar

Metode ini digunakan untuk memberikan pengetahuan kepada guru-guru SD di Kecamatan Pondok Kelapa Kabupaten Bengkulu Tengah tentang berbagai PAKEM matematika SD, salah satunya dengan menggunakan alat peraga kotak KPK dan FPB.

2. Metode demonstrasi

Metode demonstrasi pada kegiatan ini menjelaskan langsung disertai praktek kepada guru-guru SD tentang bagaimana cara penggunaan kotak KPK dan FPB serta cara pembuatannya.

3. Pengerjaan tugas terbimbing

Metode ini digunakan untuk mengetahui sejauh mana pemahaman guru-guru SD tentang pembuatan dan penggunaan kotak KPK dan FPB berorientasi PAKEM dalam matematika SD. Para peserta (guru-guru SD) ditugaskan secara kelompok untuk membuat alat peraga kotak KPK dan FPB.

4. Metode diskusi dan tanya jawab

Metode diskusi dan tanya jawab dilakukan sebagai bentuk interaksi antara peserta dan instruktur. Bertujuan untuk membantu peserta dalam pembuatan kotak KPK dan FPB serta penggunaannya dalam PAKEM matematika SD. Diskusi dan tanya jawab berlangsung selama kegiatan seminar, demonstrasi dan penugasan. Metode diskusi juga 
digunakan untuk memberikan kesempatan kepada peserta pelatihan untuk mendalami, mengembangkan, dan menyamakan persepsi tentang alat peraga matematika (kotak KPK dan FPB) dan penerapannya dalam PAKEM matematika SD.

5. Monitoring dan Evaluasi

Metode monitoring digunakan untuk mengetahui apakah peserta pelatihan menerapkan pengetahuan dan keterampilan tentang PAKEM Matematika SD dengan menggunakan kotak KPK dan FPB di sekolah masing-masing setelah mereka mengikuti kegiatan pelatihan ini.

Selama berlangsungnya kegiatan pelatihan dilakukan kegiatan pengamatan dengan menggunakan pedoman pengamatan, yaitu untuk mengetahui apakah kegiatan pelatihan berlangsung sesuai dengan rencana dan untuk mengetahui respon peserta terhadap kegiatan pelatihan.

Kegiatan pelatihan ini dikatakan berhasil, jika terjadi perubahan tingkah laku peserta pelatihan dari segi pengetahuan dan keterampilan tentang PAKEM matematika SD dengan menggunakan kotak KPK dan FPB yang ditandai dengan:

a. Kemampuan peserta pelatihan menyampaikan penggunaan kotak KPK dan FPB kepada siswa, yang ditandai dengan meningkatnya pemahaman siswa tentang konsep KPK dan FPB.

b. Kemampuan peserta pelatihan dalam membuat alat peraga matematika "kotak KPK dan FPB”, yang ditandai dengan adanya sebuah alat peraga kotak KPK dan FPB yang sudah jadi dibuat oleh setiap kelompok.

c. Respon peserta terhadap kegiatan pelatihan ini adalah baik (peserta yang memberikan respon positif $\geq 80 \%$ ).

Peserta pelatihan terdiri dari guru-guru (khususnya guru kelas) SD Negeri 10 Pondok Kelapa dan SD Negeri 2 Pondok Kelapa Kecamatan Pondok Kelapa Kabupaten Bengkulu Tengah. SD ini terletak di Desa Harapan dan Desa Pondok Kelapa, yaitu lebih kurang 6 km dari lokasi Universitas Bengkulu.

\section{HASIL DAN PEMBAHASAN}

Berdasarkan hasil wawancara dengan beberapa orang guru SD saat pelatihan ini dilakukan, pengetahuan guru-guru SD tentang PAKEM (Pembelajaran aktif, kreatif, efektif dan menyenangkan) terkait matematika SD rata-rata relatif kurang (sebanyak 95\%), dan hanya 2 orang guru $(9,1 \%)$ yang pernah mencoba menerapkan PAKEM matematika SD di sekolah mereka dan itupun hanya bisa diterapkan untuk mata pelajaran bahasa Indonesia. Para guru belum banyak mengetahui proses pembelajaran yang baik diterapkan ke siswa. Misalnya sangat jarang para guru memanfaatkan media/alat peraga pembelajaran serta lebih dominan menggunakan metode pembelajaran satu arah (konvensioanal), yaitu masih berpusat pada guru (teacher's center). Menurut Suparman (1997) bahwa strategi pembelajaran mengandung empat komponen utama, yaitu: urutan kegiatan pembelajaran, 
metode pembelajaran, media pembelajaran, dan waktu yang digunakan dalam proses pembelajaran. Oleh karena itu, untuk dapat merencanakan dan melaksanakan kegiatan pembelajaran yang sebaik-baiknya tentulah sangat tergantung dari strategi yang akan dipilih guru untuk digunakan dalam pembelajaran.

Selanjutnya Depdiknas (2005) mengemukakan bahwa PAKEM merupakan pembelajaran yang membuat atau memberikan peluang pada siswa untuk: (1) aktif bertanya, mengemukakan gagasan dan mempertanyakan gagasan orang lain dan gagasannya; (2) kreatif, yaitu merancang atau membuat sesuatu dan menulis atau mengarang; (3) menguasai keterampilan yang diperlukan; dan (4) senang yang membuat siswa berani mencoba atau berbuat, berani bertanya, berani mengemukakan pendapat dan berani mempertanyakan gagasan orang lain. Sedangkan salah satu garis besar PAKEM yaitu guru menggunakan berbagai alat bantu dan berbagai cara dalam membangkitkan semangat, termasuk menggunakan lingkungan sebagai sumber belajar untuk menjadikan pembelajaran menarik, menyenangkan dan cocok bagi siswa.

Berdasarkan hasil angket yang disebarkan ke guru-guru dalam kegiatan ini diperoleh bahwa hampir 100\% guru SD Negeri 13 Pondok Kelapa maupun SD Negeri 2 Pondok Kelapa tidak menggunakan alat peraga/media bantu dalam mata pelajaran matematika. Pada pembelajaran matematika, media pembelajaran sebagai alat bantu sesuai dengan fungsinya dapat dikelompokkan menjadi dua, yaitu alat peraga dan sarana. Sebagai alat peraga, media pengajaran membantu siswa memahami konsep matematika dalam wujud yang konkrit. Sedangkan yang masuk dalam kelompok sarana berfungsi membantu terjadinya proses belajar siswa (Supinah dan Agus, 2009).

Dalam kegiatan belajar mengajar (KBM) matematika, alat peraga berperan membantu siswa menguasai pengetahuan tentang konsep matematika yang dipelajari dalam KBM. Sebagai contoh: kotak kapur, kotak kue sebagai model geometri ruang berfungsi sebagai alat peraga apabila digunakan untuk mengajarkan konsep bangun ruang balok. Sarana berperan membantu proses belajar siswa dalam KBM untuk pembinaan keterampilan maupun untuk pemahaman konsep. Sebagai contoh tabel perkalian dua bilangan satu angka yang pengisiannya digunakan untuk beradu cepat di antara siswa merupakan kegiatan untuk membina keterampilan siswa dalam fakta perkalian dasar. Pada kesempatan lain tabel perkalian dapat digunakan dalam KBM untuk pemahaman konsep yaitu membantu siswa menemukan sifat pertukaran tempat yang dimiliki operasi hitung perkalian. Keterkaitan antara alat peraga dan kegiatan belajar untuk penanaman konsep menunjukkan bahwa macam alat peraga sesuai dengan ragam materi matematika yang dipelajari siswa dan yang tergolong sebagai pengertian baru atau pengertian dasar.

Alat peraga merupakan salah satu dari media pendidikan adalah alat untuk membantu proses belajar mengajar agar proses komunikasi dapat berhasil dengan baik dan efektif. Hal ini sesuai dengan pendapat Amir Hamzah dalam Herlina (2005) bahwa "media pendidikan adalah alat-alat yang dapat dilihat dan didengar untuk membuat cara berkomunikasi menjadi efektif'. Sedangkan yang dimaksud dengan alat peraga menurut 
Nasution dalam Herlina (2005) adalah "alat bantu dalam mengajar biar lebih efektif". Salah satu alat peraga dalam mata pelajaran matematika SD adalah kotak KPK (Kelipatan Persekutuan Terkecil) dan FPB (Faktor Persekutuan Terbesar).

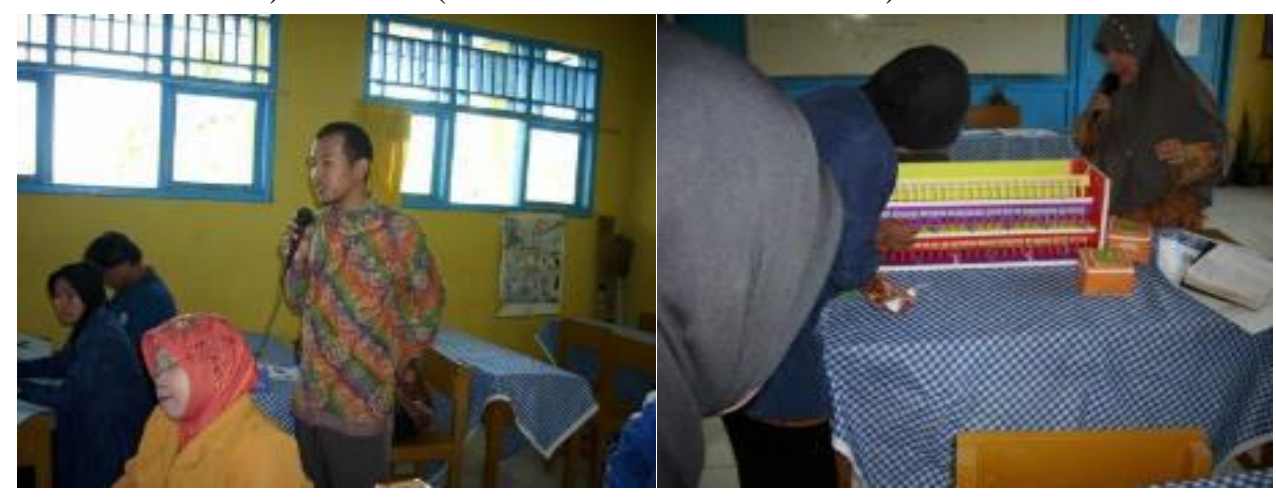

a. Kegiatan saat seminar

b. Kegiatan saat demonstrasi

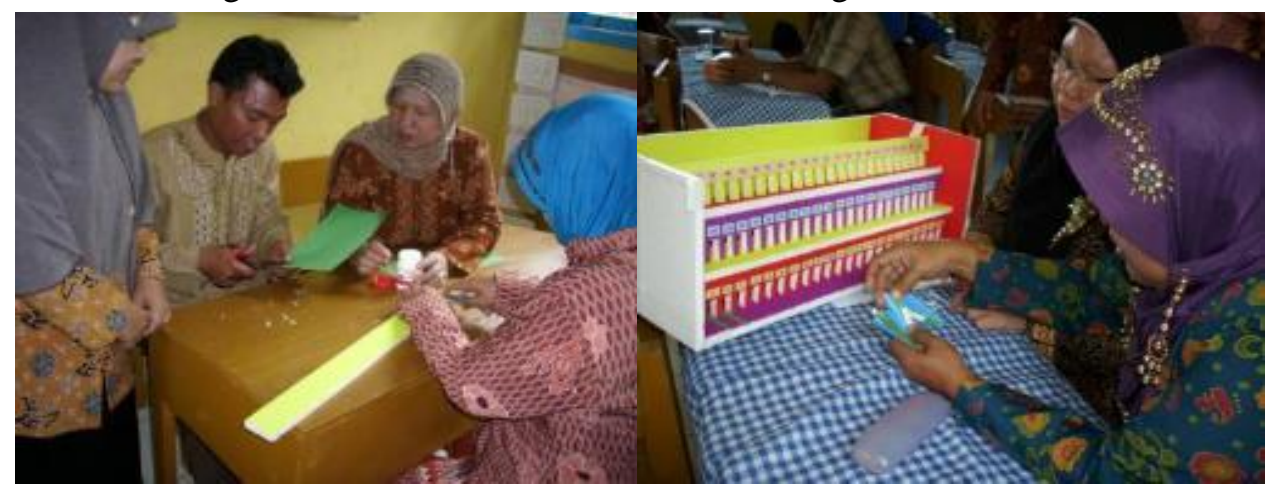

c. Pengerjaan tugas terbimbing

d. Praktek langsung

Gambar 5. Photo (dokumentasi) saat kegiatan pengabdian

Guru-guru baik di SD Negeri 12 Pondok kelapa maupun di SD Negeri 2 Pondok Kelapa pada awalnya sebanyak $100 \%$ belum memiliki pengetahuan bagaimana cara pembuatan alat peraga kotak KPK dan FPB dalam mata pelajaran matematika. Setelah workshop/seminar dilaksanakan dan setelah selesai kegiatan praktek pembuatan alat peraga ini di sekolah, maka sekitar 83\% (5 kelompok dari 6 kelompok guru) yang menghasilkan alat peraga yang lebih baik dan dapat diterapkan. Sedangkan 1 kelompok lagi belum tuntas menyelesaikan alat peraga kota KPK dan FPB dikarenakan kesalahan teknis, namun secara umum (sekitar 95\%) respon guru terhadap kegiatan ini sangat baik (positif) dan pengetahuan mereka tentang PAKEM matematika SD menjadi lebih meningkat.

Contoh penerapan Kotak KPK dan FPB:

Soal:

Mencari Kelipatan Persekutuan Terkecil (KPK) dari 4, 6, 8. Jawab:

Kelipatan dari 4 adalah : 4,8,12,16,20,24,28.32.36.40,44,48,52,56,60

Ambil kertas putih dan masukkan pada kotak nomor: 
$4,8,12,16,20,24,28.32 .36 .40,44,48,52,56,60$

Seperti contoh pada gambar:

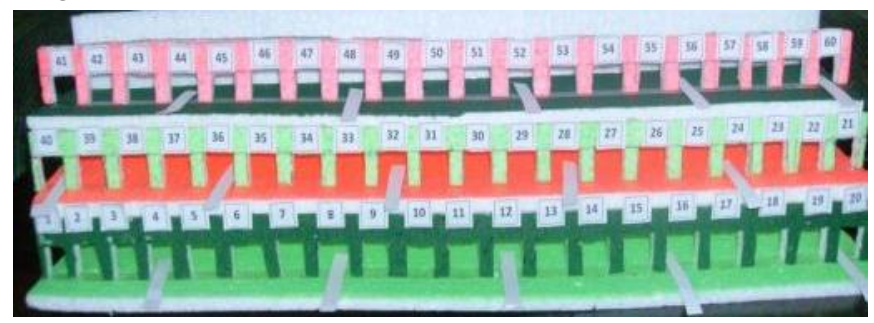

Kelipatan dari 6 adalah: 6,12,18,24,30,36,42,48,54,60

Ambil kertas kuning dan masukkan pada kotak nomor : 6,12,18,24,30,36,42,48,54,60

Seperti contoh pada gambar:

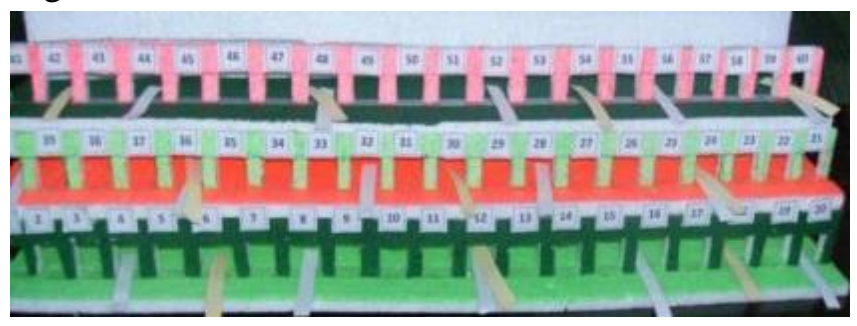

Kelipatan dari 8 adalah: 8,16,24,32,40,48,56

Ambil kertas kuning dan masukkan pada kotak nomor : 8,16,24,32,40,48,56

Seperti contoh pada gambar:

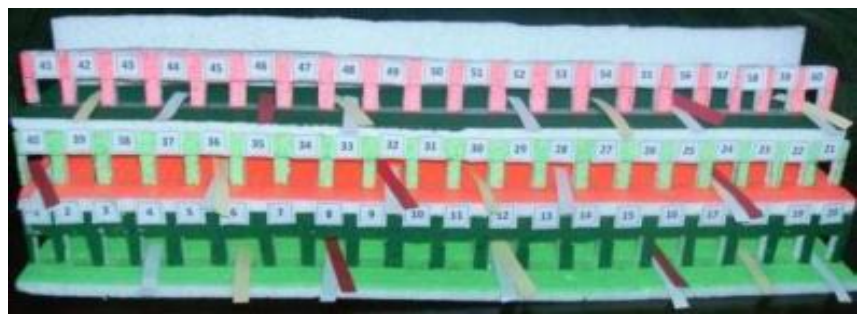

Amatilah mana kotak yang isinya tiga kartu, dan kotak yang isinya kurang dari tiga kartu. Ambil kertas dari kotak yang isinya kurang dari tiga kartu dan tinggalkan kertas dalam kotak yang isinya tiga kartu.

Diantara kotak yang isinya tiga kartu mana angka yang terkecil? tinggalkan kartu dengan angka terkecil dalam kotak dan ambil kartu lainnya dalam kotak. Jadi KPK dari 4,6,8 adalah 24.

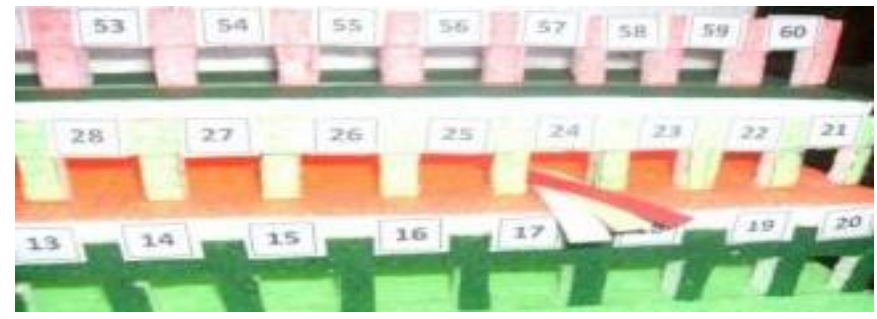


Soal:

Menentukan FPB dari 70, 80, 90.

Jawab:

Faktor dari 70 adalah : 2, 5, 7, 10, 14, 35

Ambil kertas putih dan masukkan pada kotak nomor : 2, 5, 7, 10, 14, 35

Seperti contoh :

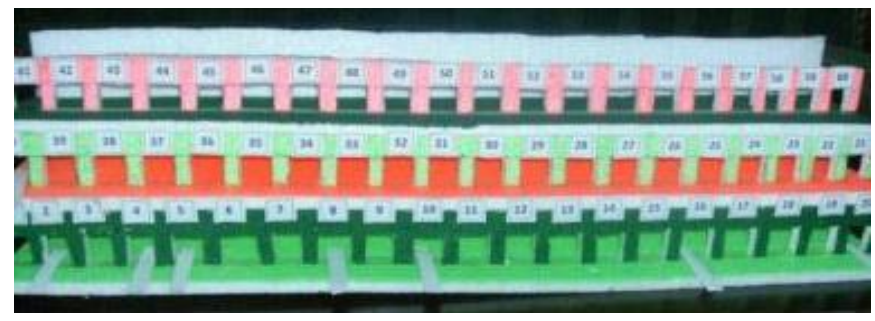

Faktor dari 80 adalah : 2, 4, 5, 8, 10, 16, 20, 40

Ambil kertas kuning dan masukkan pada kotak nomor : 2, 4, 5, 8, 10, 16, 20, 40

Seperti contoh :

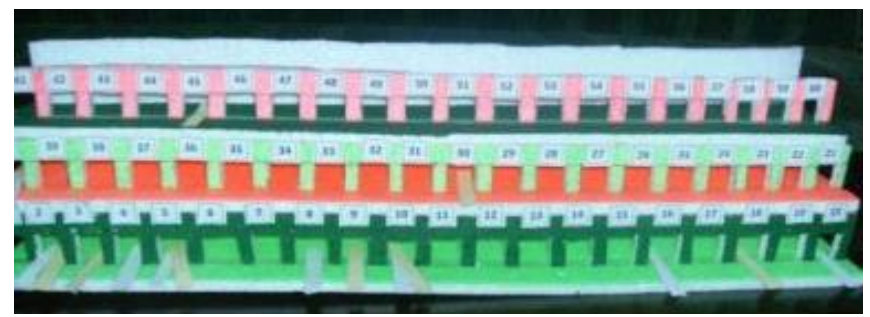

Faktor dari 90 adalah : 2, 3, 5, 10, 18, 30, 45

Ambil kertas kuning dan masukkan pada kotak nomor : 2, 3, 5, 10, 18, 30, 45

Seperti contoh :

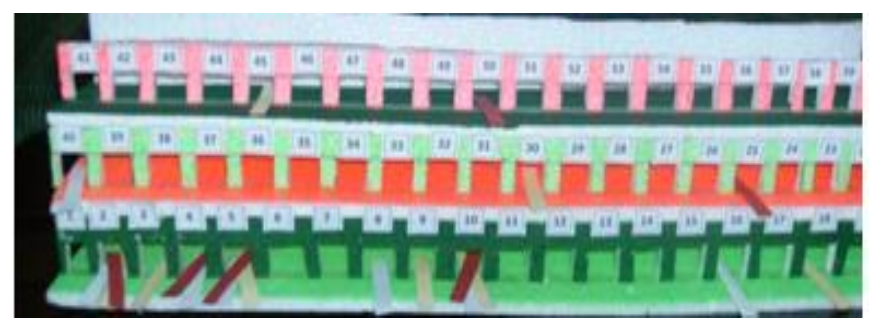

Selanjutnya, amatilah, mana kotak yang berisi 3 kartu dan kurang dari tiga kartu. Ambil kartu dalam kotak yang berisi kurang dari dua kartu dan biarkan kotak yang berisi tiga kartu. Yang tersisa adalah kotak nomor 2, 5 dan 10. 


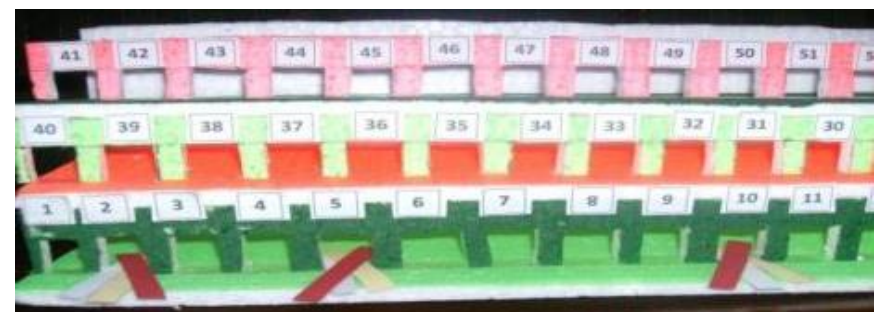

Dari tiga kotak yang berisi tiga kartu maka kotak yang memiliki angka tertinggi adalah kotak nomor 10 .

Ambil kartu yang berada pada kotak nomor 2 dan 5 .

Kartu yang tersisa adalah kartu yang berada pada kotak nomor 10. Jadi FPB dari 70, 80 dan 90 adalah 10.

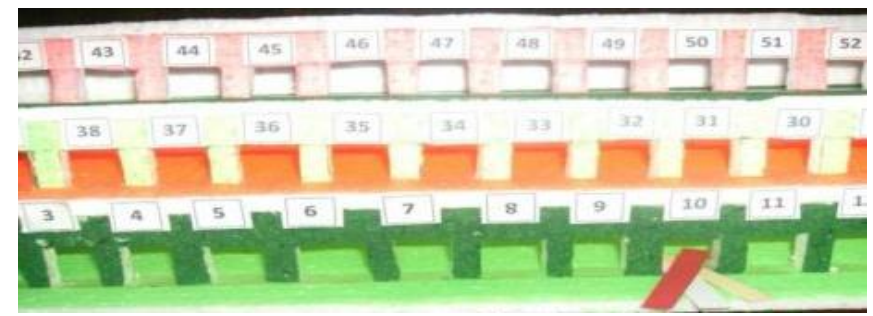

\section{KESIMPULAN DAN SARAN}

\section{Kesimpulan}

1. Pengetahuan guru-guru SD di Kecamatan Pondok Kelapa Kabupaten Bengkulu Tengah tentang PAKEM matematika relatif kurang yaitu hanya 9,1\% yang mengetahui tentang PAKEM matematika SD.

2. Kemampuan dan keterampilan guru-guru SD di Kecamatan Pondok Kelapa Kabupaten Bengkulu Tengah dalam membuat alat peraga kotak KPK dan FPB tergolong baik (sekitar 83\%) kelompok peserta pelatihan menghasilkan alat peraga ini dengan hasil baik dan bisa diterapkan pada mata pelajaran matematika.

3. Motivasi guru mengikuti pelatihan ini tergolong baik (respon positif peserta pada angket sebesar 95\%).

\section{Saran}

Berdasarkan hasil kegiatan pelatihan, maka disarankan kepada pihak-pihak yang terkait dan berkepentingan dengan masalah pembelajaran matematika, yaitu sebagai berikut:

1. Perlu dilakukan sosialisasi maupun pelatihan tentang PAKEM matematika kepada para guru maupun siswa pada jenjang SMP maupun SMA.

2. Institusi pendidikan, baik SD, SMP, maupun SMA perlu menyusun Rencana Pembelajaran yang berorientasi PAKEM khususnya mata pelajaran matematika yang bersifat abstrak. 


\section{DAFTAR PUSTAKA}

Depdiknas, 2005, Contoh Model PAKEM Matematika SD, Dirjen Pendidikan Dasar dan Menengah, PPPG Matematika, Yogyakarta.

Herlina, C., 2005, Upaya untuk Menguji Efektifitas Pengajaran dengan Menggunakan Alat Peraga yang akan Dibandingkan dengan Pengajaran Tanpa Menggunakan Alat Peraga, UNNES, Semarang.

Suparman, 1997, Strategi Pembelajaran Matematika SD, Raja Grafindo Persada, Jakarta.

Supinah dan Agus, 2009, Media Pembelajaran, Rineka Cipta, Jakarta. 